\title{
PREVIDÊNCIA PRIVADA: A BOA-FÉ OBJETIVA E A FUNÇÃO SOCIAL COMO FILTRO NOS CONTRATOS RELACIONAIS
}

\section{PRIVATE PENSION: OBJECTIVE GOOD FAITH AND SOCIAL FUNCTION AS A FILTER IN RELATIONAL CONTRACTS}

\author{
Francisco José Cahali \\ Pontifícia Universidade Católica de São Paulo - PUC-SP - (São Paulo, SP, Brasil) \\ Danielle Portugal de Biazi \\ Pontifícia Universidade Católica de São Paulo - PUC-SP - (São Paulo, SP, Brasil) \\ Recebimento: 30 jun. 2019 \\ Aceitação: 24 nov. 2019
}

\begin{abstract}
Como citar este artigo / How to cite this article (informe a data atual de acesso / inform the current date of access):
CAHALI, Francisco José; BIAZI, Danielle Portugal de. Previdência privada: a boa-fé objetiva e a função social como filtro nos contratos relacionais. Revista da Faculdade de Direito UFPR, Curitiba, PR, Brasil, v. 65, n. 1, p. 101-126, jan./abr. 2020. ISSN 2236-7284. Disponível em: <https://revistas.ufpr.br/direito/article/view/67708>. Acesso em: 30 abr. 2020. DOI: http://dx.doi.org/10.5380/rfdufpr.v65i1.67708.
\end{abstract}

\section{RESUMO}

A propósito dos debates em torno da reforma da previdência e da crise do Estado de bem-estar social, o presente artigo se propõe a uma reflexão da previdência privada à luz da teoria geral do direito contratual, notadamente em virtude de o Brasil se encontrar entre os dez países com os maiores sistemas de fundo de pensão do mundo. O objetivo do presente artigo, portanto, é expor descritiva e analiticamente os contratos de previdência privada e sua natureza relacional, bem como compreender a interpretação das cláusulas gerais da função social dos contratos e a boa-fé objetiva na previdência complementar como métodos de proteção dos contratantes em um serviço privado de relevância pública. A partir disso, foi necessária uma pesquisa exploratória de abordagem qualitativa acerca do modelo previdenciário brasileiro, identificando sua natureza contratual dotada de catividade, o que fomenta particular atenção no que toca à tutela da confiança. Por fim, a conclusão foi para ressaltar o relevante valor social dos contratos de previdência privada como braço de auxílio, embora não substituto, da seguridade social, o que outorga ao Estado maior poder intervencionista mediante a exigência de observância dos ditames da boa-fé objetiva e da função social dos contratos, típicos das relações privadas, como filtros rígidos na consagração dos fundamentos constitucionais de solidariedade, dignidade humana e justiça social na construção da unidade do ordenamento jurídico hierarquicamente sistematizado.

\section{PALAVRAS-CHAVE}

Previdência privada. Contratos relacionais. Boa-fé objetiva. Função social dos contratos.

\begin{abstract}
Based on the debates surrounding the social security reform and the crisis of the welfare state, this article proposes a reflection on private pension in the light of the general theory of contractual law, especially because Brazil ranks among the ten countries with the largest pension fund systems in the world. The purpose of this article, therefore, is to present descriptive and analytically private pension
\end{abstract}


contracts and its relational nature, as well as understand the interpretation of the general clauses of the social function of contracts and objective good faith in supplementary pensions and contractors protection methods in a private service of public relevance. From this, it was necessary an exploratory research of qualitative approach about the Brazilian social security model, identifying its relational nature, which promotes particular attention on trust. Finally, the conclusion was to emphasize the relevant social value of private pension contracts as an additional branch, although not a substitute for social security, which gives the state a greater interventionist power through the requirement of observance of the dictates of objective good faith and social function of contracts, typical of private relations, as rigid filters in the consecration of constitutional foundations of solidarity, human dignity and social justice in the construction of the unity of the legal system, as long as the hierarchy of laws is observed.

\section{KEYWORDS}

Private pension. Relational contracts. Objective good faith. Social function of contracts.

\section{INTRODUÇÃO}

O sistema de seguridade social no Brasil vem passando ao longo dos anos por uma série de reformas e regulamentações, notadamente após a Constituição Federal de 1988, que consagrou a retomada da República e o Estado social (BRASIL, 1988). Com isso, passaram a integrar o sistema de previdência (um dos pilares da seguridade) uma série de sujeitos antes não contemplados, sejam trabalhadores autônomos, donas de casa, sem contar com a ampliação dos benefícios aos trabalhadores rurais.

Também pelo texto da Carta de 1988, notadamente após a Emenda Constitucional de 1998, restou consagrada a previdência complementar privada a se desenvolver contratualmente por entidades não estatais. Muito embora a Lei $n^{\circ} 6.435$ de 1977 já houvesse regulamentado a questão em alguma medida, é possível afirmar que somente na década de 1990 e início dos anos 2000, com relevante atraso, por assim dizer, o tema apresentou maior segurança aos participantes e beneficiários.

Malgrado a Constituição Cidadã tenha exaltado um sistema solidarista pelo qual a comunidade ativa, em contribuição obrigatória, formaria um fundo apto a garantir a aposentadoria dos inativos, uma série de obstáculos passou a desequilibrar o sistema atuarial público: aumento da população idosa, diminuição da população jovem e contribuinte, excessos na concessão de benefícios e instabilidade econômica.

Desde o ano de 2014, o país atravessa uma sucessão de crises de cunho político e econômico que inflaram um clamor pela chamada reforma da previdência. A pauta do Congresso Nacional tem se dedicado a debater o assunto, assim como a sociedade civil encontra-se absolutamente insegura sobre a viabilidade de suas aposentadorias no futuro. 
A partir desse conjunto de fatores, a previdência privada tornou-se cada vez mais uma opção aos que na idade ativa contribuem, mas que na aposentadoria recebem valores abaixo do esperado para manutenção do padrão de vida. Houve claramente um fomento na adesão de planos de previdência complementar, seja por meio de entidades abertas, seja por meio de entidades fechadas.

Nesse sentido, insta salientar que o trabalho contemplará visão da previdência complementar fechada e aberta, uma vez que ambas possuem o mesmo arcabouço constitucional, desenvolvendo-se sob o regime de contratação privada que, por sua vez, permite a incidência de princípios como a função social e a boa-fé objetiva, vetores do direito civil pátrio.

Feitas essas primeiras observações, pelo estudo do modelo previdenciário brasileiro, a presente pesquisa se propõe a contextualizar o contrato de previdência como um braço da seguridade social e negócio jurídico privado concretizador dos ideais constitucionais de solidariedade e justiça social.

Já no segundo capítulo, dedicando-se especialmente à espécie negocial complementar, o trabalho pretende alocá-la na classificação dos contratos relacionais - isso justificará a interpretação adotada pelos tribunais na ainda incipiente jurisprudência quanto ao assunto. Para tanto, serão apresentadas as posições de doutrinadores nacionais que se dedicaram aos estudos dos chamados contratos relacionais ou cativos de longa duração, inclusive com a apresentação da origem da teoria no estrangeiro pelo jurista Ian R. Macneil.

Identificada essa primeira premissa, justificam-se a aplicação dos grandes filtros do direito contratual: a boa-fé objetiva e a função social dos contratos. A boa-fé objetiva entra como promotora da tutela da confiança exigível em maior grau nos contratos de longa duração como a previdência complementar. Por esse vetor, o Poder Judiciário outorga aos participantes maior segurança quanto às expectativas criadas no processo obrigacional.

Pela função social dos contratos, quarto capítulo da pesquisa, é possível verificar os efeitos existenciais que espraiam de uma relação privada, produzindo resultados não apenas para os sujeitos envolvidos, mas para toda a coletividade, posto que a previdência privada produz serviços de relevância social ao contribuir diretamente com o Estado na proteção dos trabalhadores inativos, seja em razão do tempo de contribuição, seja em razão da idade, seja em razão de saúde debilitada.

Diante do contexto apresentado, o trabalho se propõe a apresentar o contrato de previdência privada como um notável exemplo da constitucionalização do direito civil e promotor dos direitos existenciais, na medida em que nasce do legítimo manifestar da autonomia privada, porém cujo alcance, por seus elementos e dinâmica, promove valores essenciais ao equilíbrio social, merecendo dirigismo à luz das cláusulas gerais da boa-fé objetiva e da função social dos contratos. 


\section{MODELO PREVIDENCIÁRIO BRASILEIRO}

O modelo de previdência social no Brasil vem contemplado pela Constituição da República de 1988 como um direito social, conforme se depreende dos artigos $6^{\circ}$ e $7^{\circ}$ e, com maior especificidade, no Capítulo II, da Seguridade Social, que a partir do artigo 201 apresenta um regime geral de filiação obrigatória, sem, contudo, excluir o regime de previdência privada, cuja adesão será facultativa e regulada por lei complementar, nos termos do artigo 202 e seus parágrafos.

Desde a promulgação da Constituição Cidadã, muitas foram as emendas constitucionais e reformas legislativas que atingiram a previdência, notadamente em cenários de crise econômica e mediante o discurso de déficit marcado pela diminuição da massa de contribuintes associada ao crescimento da população idosa e à pressão de órgãos internacionais.

As contribuições no regime obrigatório são o próprio fomento da seguridade social, verificado pela previsão do artigo 195 da Constituição Federal: “A seguridade social será financiada por toda a sociedade”, e veda-se ao Estado a utilização destes recursos para fins não relacionados ao regime geral da previdência, pela letra do artigo 167, inciso XI. A dinâmica visa blindar o sistema, garantindo, de certa forma, a existência de fundos para pagamentos das pensões e aposentadorias da população, excluindo até mesmo a destinação para o regime previdenciário dos servidores públicos.

Dentro dessa realidade impõe compreender que a seguridade social é um dos instrumentos na busca pela redução das desigualdades sociais, erradicação da pobreza, promoção do bem comum e construção de uma sociedade livre, justa e solidária, nos ditames do artigo $3^{\circ}$ da Constituição Federal.

Mattia Persiani (2014, p. 27) explica com clareza o traço de promoção social da seguridade:

L’idea della sicurezza sociale trova, dunque, la sua essenziale attuazione in quel complesso sistema attraverso il qual ela pubblica amministrazione, o altri enti pubblici, realizzano il fine pubblico della solidarietà con l'erogazione di beni, in danaro o natura, e di servizi ai cittadini che si trovano in condizioni di bisogno.

Com isso fica claro que a previdência social carrega consigo forte traço de política pública de distribuição de rendas e inclusão. A Carta Magna brasileira, tipicamente oriunda de um constitucionalismo voltado ao social, coloca o Estado como agente capaz de providenciar as medidas preliminares para amenizar as fragilidades coletivas - essas se dão não somente em ações privativas, mas também pela intervenção na ordem econômica e social.

Daí porque, superada a filosofia do estado liberal, a Constituição de 1988 é um referencial de valores igualitários e humanistas que, contudo, ainda carece de instrumentos processuais ou 
técnicas capazes de efetivar os direitos sociais básicos dos cidadãos - grande desafio, segundo Paulo Bonavides (2004, p. 373).

Uma das formas de efetivação dos direitos sociais, entre eles a previdência social, meio de distribuição de renda e inclusão, é o desenvolvimento de políticas públicas pelo Estado. O conceito de políticas públicas é inquestionavelmente aberto, todavia, tem sido compreendido por alguns autores como programas ou quadros de ação governamental que promovam um conjunto de medidas coordenadas (BUCCI, 2006, p. 14).

Wagner Balera (2011, p. 370) bem conclui pela insuficiência da previsão constitucional de um direito, revelando-se patente que a legalidade dê ao seu titular o poder de exigir a prestação que lhe é devida.

Certo é que no plano da previdência social é possível identificar uma estrutura complexa de políticas públicas e legislações aptas a garantir a implementação do mencionado direito social. Isso se identifica por meio do planejamento orçamentário e da identificação dos sujeitos vinculados.

Pelo planejamento orçamentário, pela delimitação dos sujeitos ativos e passivos ficam traçados os paradigmas gerais da previdência social, que no Brasil divide-se basicamente em três: regime geral, regime próprio e regime complementar.

A regra, ao menos o espírito do constituinte, era de que o poder público fosse o principal sujeito passivo no que toca à seguridade social. Tudo isso decorre de um viés de bem-estar (welfare state), que compreende a solidariedade constitucional concretizada mediante a repartição dos recursos recolhidos dos contribuintes ativos a fim de beneficiar os inativos (MUSSI, 2010, p. 155).

Fato é que o Brasil vem atravessando aprofundada crise econômica e muito tem-se questionado acerca da viabilidade do regime previdenciário atual. Há um projeto de reforma profunda sendo debatido no Congresso Nacional, vinculado a uma sensação de desamparo da população, visto que milhões de brasileiros sobrevivem da previdência.

De outro lado, há uma insegurança e insatisfação daqueles que contribuem com aportes mais elevados e deparam-se, no momento da aposentadoria, com benefícios aquém do padrão de vida experimentado. Esse grupo passa a integrar e fomentar a previdência privada, regime de caráter facultativo e complementar, pelo qual "o participante [...] verte seu dinheiro para um fundo próprio, que será formado para a manutenção de sua aposentadoria especificamente.” (BALERA; MUSSI, 2010, p. 39). Naturalmente, o regime de previdência pública não se presta, tampouco tem como meta, garantir a manutenção do padrão de vida dos segurados; o que se coloca em questão, neste ponto, é que camadas sociais com maiores reservas acabam por optar por regimes complementares e, destarte, encontrar maior solidez no futuro. 
Em outras palavras, observa-se que pelo regime de previdência pública no Brasil, somente serão remunerados com o valor integral dos rendimentos enquanto ativos, os trabalhadores identificados como de baixa renda, ao passo que as classes média e alta acabam remuneradas com valores inferiores ao tempo que estavam ativas. O desequilíbrio atuarial remete a razões históricas e institucionais. Nesse sentido, estudo entabulado ainda em 2007 identificou, num contexto de 20 países (10 europeus, seis americanos e quatro asiáticos), que o Brasil era aquele com menor restrição à obtenção de benefícios e aposentadorias (TAFNER, 2007, p. 9), provocando descompasso nas contas públicas, que não arrecadam na mesma proporção das concessões - nesse ponto, os grandes prejudicados são os estratos populacionais mais carentes.

Diversas alterações legislativas vêm ocorrendo desde então, todavia, poucas soluções para os alegados descompassos na previdência social mostraram-se eficazes, o que continua contribuindo para o aumento da procura, pelas classes média e alta nacionais, de contratos privados que assegurem a aposentadoria.

Os regimes complementares da previdência, como dito, encontram-se previstos pelo artigo 202 da Constituição da República. O caráter é facultativo, isto é, decorrem da autonomia privada e baseiam-se na constituição de uma espécie de fundo que, ao final, garanta o benefício ao contratante.

Atualmente o sistema é regido pelas Leis Complementares no 108 e 109 de 2001 (BRASIL, 2001a, 2001b). A Lei Complementar $n^{\circ} 109$ (BRASIL, 2001b), já em seu artigo inaugural, traça as linhas principais do modelo: complementar, autônomo e facultativo. Complementar justamente no sentido de que o regime geral obrigatório garante remuneração até determinado teto, tido como essencial. Autônomo porque independe da filiação ao regime da previdência pública, e facultativo porque decorre de um contrato de adesão, pressupondo, portanto, uma manifestação de vontade do beneficiário.

Dentro desse contexto, estão estruturadas duas formas de adesão ao regime complementar operado por instituições privadas. O primeiro deles é aquele descrito no artigo 31 da Lei Complementar $n^{\circ} 109$ de 2001 (BRASIL, 2001b), gerido por entidades fechadas, também chamadas fundos de pensão, sem finalidade lucrativa. Segundo dados extraídos da Superintendência Nacional da Previdência Complementar (Previc), o Brasil possui o oitavo maior sistema de fundos de pensão do mundo quando contabilizado o ativo total, incorporando mais de 300 entidades de previdência complementar fechadas, que controlam a administração de 1.100 planos de benefícios (BRASIL, 2014a).

De outro lado, dados da Federação Nacional de Previdência Privada e Vida (FenaPrevi) (2019) indicam que atualmente os planos privados de previdência contemplam 13,2 milhões de 
pessoas, o que corresponde a 6\% da população brasileira, indicando uma linha de crescimento após um período de recessão identificado em meados de 2015.

Nessa realidade, podem se vincular apenas aqueles que possuírem relação empregatícia ou associativa com a entidade instituidora (fundações ou sociedades civis). Na atual gestão, a previdência social, incluindo a complementar fechada, é coordenada e fiscalizada pela Secretaria de Previdência, apêndice do Ministério da Economia.

O segundo modelo é por entidades abertas, com finalidade lucrativa e previsto no artigo 36 da Lei Complementar nº 109 de 2001 (BRASIL, 2001b). Nesta hipótese, fica dispensado o vínculo empregatício ou associativo. Os planos são disponibilizados abertamente no mercado por meio de entidades constituídas como sociedades anônimas, submetendo-se à fiscalização da Superintendência de Seguros Privados (Susep) e à regulação do Conselho Nacional de Seguros Privados.

Dito isso, o presente trabalho visa dedicar-se notadamente às especificidades do contrato de previdência privada, seja aberta ou fechada, analisando sua natureza e a incidência dos filtros da função social dos contratos e da boa-fé objetiva, vetores interpretativos justamente em momento histórico de crise e de ascendente debate em torno da reforma da previdência.

\section{CONTRATOS DE PREVIDÊNCIA PRIVADA COMO CONTRATOS RELACIONAIS}

Os contratos de previdência privada são, em regra, contratos de adesão de longuíssima duração, na medida em que funcionam como um fundo do qual o beneficiário extrairá uma aposentadoria complementar.

Por carregarem roupagem própria, Cláudia Lima Marques (1995, p. 57) insere os contratos de previdência privada no nicho dos chamados contratos cativos de longa duração, conceituados pela autora como "relações contratuais que utilizam métodos de contratação de massa, para fornecer serviços especiais no mercado, criando relações jurídicas complexas de longa duração [...]”.

Todavia, embora a longa duração seja característica frequente da previdência complementar, não lhe é essencial, razão pela qual alguns autores preferem optar pela classificação de contratos relacionais (MACEDO JÚNIOR, 2011a, p. 1.073). Ainda, segundo Ronaldo Porto Macedo Junior (2011a, p. 1.073), os contratos de previdência privada, assim como de planos de saúde e algumas espécies de contratos bancários, possuem como característica a mutabilidade e alto grau de flexibilidade nas prestações - indeterminação e, por fim, complexidade.

O autor explica que, considerados os elementos que compõem contratos relacionais, seu conteúdo passa de cláusulas substantivas para cláusulas de regulamentação do processo de 
renegociação (MACEDO JÚNIOR, 2011b, p. 664). Em outras palavras, há tantos pontos sensíveis nas contratações relacionais que o negócio jurídico fica mais adstrito aos termos da mutabilidade do que a padrões substantivos absolutos.

Ruy Rosado de Aguiar Júnior (2011, p. 98), ao tratar do tema dos contratos relacionais, assim os define: “negócio jurídico perfeito e incompleto, no qual a determinação do seu conteúdo ou de alguns dos seus elementos essenciais se realiza mediante a remissão de elementos estranhos ao mesmo”.

Insta salientar que o conceito de contratos relacionais no Brasil, aplicável aos negócios jurídicos de previdência privada, decorre dos estudos do jurista escocês Ian R. Macneil, mas com eles não se confunde. Macneil passou a discutir uma nova perspectiva contratual diante das relações massificadas e de longa duração, prevendo a necessidade de uma nova teoria geral dos contratos. Segundo o autor, pelos contratos relacionais as partes se envolvem continuamente em um negócio cujo termo final resta em aberto. Justamente por contar com altíssimo grau de indeterminação, são negociações que demandam excepcional cooperação e confiança entre as partes contratantes.

O que Macneil (2003, p. 210) pretendia dizer é que a estrutura clássica de contratos permite que o intérprete analise apenas os termos expressos do negócio, deveres tido como centrais. Contudo, na atual complexidade de regulamentos e litígios, a análise estrita aos termos expressos é deficitária, porque não contempla o contexto em que o contrato foi produzido ou no qual vem sendo questionado. Daí por que o autor entende que todos os contratos contemporâneos são relacionais, já que todos refletem a situação normativa constituída no momento de sua formação e execução. Naturalmente, o autor reconhece em sua obra que há contratos mais simplificados no tráfego negocial, o que torna alguns negócios “mais relacionais que outros”.

Há, nessas figuras contratuais, o conceito de solidariedade, que aqui deve ser compreendido como uma expectativa comum dos contratantes de que as vulnerabilidades não serão exploradas; em outras palavras, que as partes cooperarão para que ambas tirem benefícios econômicos daquela transação, que se prolongará indefinidamente (FERES; DIAS, 2011, p. 339). A ideia de Macneil (2003), em apertada síntese, seria estabelecer limites ao liberalismo, pela contextualização do negócio em seu meio social (MACEDO JUNIOR, 2013).

Naturalmente que a cooperação e confiança supramencionadas decorrem dos deveres anexos essenciais em qualquer relação contratual. Também é verdade concluir que tais deveres são variáveis, embora não prescindíveis, a depender dos sujeitos contratantes e dos elementos essenciais do negócio entabulado, conforme posicionamento de Cláudia Lima Marques (1998, p. 38). 
Os principais estudiosos da teoria dos contratos relacionais no Brasil, tal como os já mencionados Ronaldo Porto Macedo Junior, Ruy Rosado de Aguiar e Cláudia Lima Marques tendem a concluir que para o sistema jurídico brasileiro, diferentemente de Ian Macneil, não se trata de uma nova teoria contratual, mas sim hipótese classificatória que, por sua natureza, abre ampla margem para aplicação de cláusulas gerais como a boa-fé objetiva e função social dos contratos.

Os tribunais pátrios pouco se debruçaram sobre o tema. Contudo, o Superior Tribunal de Justiça, em abordagens ainda incipientes, tem colocado os contratos de previdência privada no nicho de contratos relacionais, tal como defendido neste trabalho. Merece particular atenção o voto-vista proferido pelo Min. Paulo de Tarso Sanseverino, nos autos do Recurso Especial n. 1.201.529/RS, julgado pela Segunda Seção em março de 2015.

Em sua fundamentação, Sanseverino aloca a previdência privada na "modalidade de contratos relacionais, de trato sucessivo e de longa duração, em que podem ocorrer alterações ao longo da relação negocial, mediante negócios jurídicos supervenientes [...]”. Referida decisão é uma das poucas oportunidades em que é reconhecida, para além da doutrina, a condição de catividade, muito embora o acórdão tratasse especificamente de uma tese decadencial, não aprofundando a temática classificatória.

Em outras oportunidades, a figura dos contratos relacionais surge para abordar contratos de planos de saúde e de seguros de vida. Ainda que para tratar de figuras contratuais distintas, há em acórdão proferido pela $3^{\mathrm{a}}$ Turma, sob relatoria da Min. Nancy Andrighi (BRASIL, 2014b), interessante concepção, complementar às análises de colaboração e solidariedade introduzidas neste texto. No Recurso Especial n. 1.294.093/RJ, Andrighi defende a relação de confiança estabelecida pelos contratos relacionais como uma baliza capaz de mitigar o princípio do pacta sunt servanda, muito embora, na hipótese, tenha votado pela não renovação de um seguro de vida, dada a reduzida duração contratual, inapta a atrair os efeitos dos contratos relacionais.

Pelas características ventiladas, revela-se imperioso inserir no campo dos contratos de previdência privada a classificação de contratos relacionais ou cativos. Veja-se que, na hipótese, os chamados participantes espontaneamente aderem a um plano de determinada entidade mediante um negócio jurídico bilateral constitutivo de direitos e obrigações para ambas as partes, com provável longa duração.

De um lado, a relação implica a segurança do participante de que o período ativo de colaboração ajudará a constituir uma espécie de poupança apta a complementar sua aposentadoria, sendo-lhe conferido o direito de circular entre planos distintos (portabilidade), fazer aportes, nomear beneficiários. De outro lado, a entidade responsável por gerir e constituir as reservas deve assegurar 
transparência, solvência e equilíbrio atuarial, garantindo ao participante a oferta de um benefício compatível ao escolhido no momento da adesão. As peculiaridades não acabam aí: na previdência complementar de capital fechado, há a figura do patrocinador, que estabelece um vínculo institucional com a entidade operadora por meio de um plano de adesão previsto no artigo 13 da Lei Complementar $n^{\circ} 109$.

Sendo um contrato complexo, duradouro e de renovações continuadas, nada mais pungente do que compreendê-lo como contrato relacional. Daí porque, estabelecidas essas premissas, revelase demasiadamente importante identificar as balizas interpretativas que recaem sobre contratos de referida natureza.

\section{BOA-FÉ OBJETIVA COMO VETOR NOS CONTRATOS DE PREVIDÊNCIA PRIVADA}

Bastante já foi mencionado sobre a natureza relacional dos contratos de previdência privada. Nesse mesmo contexto, ressalta-se a posição de toda a doutrina no sentido de que negociações representativas de catividade, como é o caso, demandam também atenção especial às regras da boafé objetiva.

Em outras palavras, isso significa que para além dos deveres nucleares da contratação, as partes devem observar os deveres anexos consistentes de cooperação, confiança e solidariedade. Nada mais se trata do que um agir ético e leal, esperado dentro da dinâmica contratual desenvolvida.

Não se trata de um padrão fechado de comportamento, mas de um standard aplicável especificamente na hipótese. A demanda decorre justamente do fato de que são contratações, em regra, duradouras, e cujas cláusulas guardam certa flexibilidade a fim de se adequar a mudanças de regulamentação e dos próprios interesses envolvidos.

Clóvis V. do Couto e Silva (2006, p. 163), ao tratar de obrigações duradouras, bem pontua que há relações nas quais “o adimplemento sempre se renova sem que se manifeste alteração no débito. Essas obrigações são mais ricas numa dimensão: no tempo, no elemento duradouro, que se relaciona com a essência do dever de prestação”.

Dentro desse processo obrigacional a cooperação assume posição de destaque. É compreender que, para a satisfação dos interesses que exsurgem do contrato, todas as partes devem atuar de modo a obter o resultado útil da prestação. Nem sempre essa conduta se reduz a deveres constantes de uma cláusula contratual, ou de uma determinação legal. Nessas hipóteses, fala-se em deveres anexos que concretizam a boa-fé objetiva (MARTINS-COSTA, 2018, p. 234-235).

A autora bem elucida a questão quando assim discorre: 
Uma outra espécie de deveres correspondentes aos interesses de prestação inconfundíveis com os principais e com os secundários é a dos (ii) deveres anexos, ou instrumentais. [...] Como sua denominação indica, atuam para otimizar o adimplemento satisfatório, fim da relação obrigacional. São deveres que não atinem ao "que” prestar, mas ao "como" prestar. Podem estar previstos em lei (como dever de prestar contas, que incumbe aos gestores e mandatário em sentido amplo) ou não, mas o seu fundamento último estará sempre na boafé - seja por integração contratual diretamente apoiada no texto legal, seja pela integração por via da concreção do princípio da boa-fé (MARTINS COSTA, 2018, p. 241-242).

Em outras palavras, em um contrato de previdência privada, o participante tem uma série de possibilidades que envolvem até mesmo mudanças no valor depositado mensalmente, portabilidade para aderir a um programa que melhor atenda seus anseios, realização de aportes, levantamentos, e indicação de beneficiários, tudo sem desconstituir a relação jurídica estabelecida.

De outro lado, existe um conteúdo de confiança de que o fundo gerido será disponibilizado dentro dos padrões esperados, mesmo após longos anos; de que a entidade se manterá solvente; ou que o vínculo não será rompido de modo unilateral sem a devida notificação e justificação prévia, considerada a expectativa depositada no negócio.

Referidas relações contratuais, pela própria dinâmica que assumem, portanto, implicam tratamento especial. Trata-se de proteção especial aos que mantêm contratações duradouras e que, portanto, tem como legítima a manutenção de suas expectativas.

Isso não significa dizer que a boa-fé objetiva é conceito aplicável apenas em algumas relações, mas reconhecer que há filtros mais rígidos para a interpretação de figuras relacionais, como os contratos de previdência, que, não bastasse a própria dinâmica, ainda complementam uma garantia constitucional relativa à seguridade social.

A boa-fé objetiva tem natureza de cláusula geral e vem prevista expressamente tanto no Código Civil (BRASIL, 2002) como no Código de Defesa do Consumidor (BRASIL, 1990). Seus efeitos se espraiam por todo o iter obrigacional, incluindo a fase pré-contratual e pós-contratual. A esse respeito, Menezes Cordeiro (2015, p. 583) leciona que a responsabilidade pela quebra da boa-fé objetiva na fase pré-contratual, ou culpa in contrahendo, implicaria basicamente três deveres anexos: de proteção, de informação e de lealdade.

Incorpora-se aos deveres de proteção a ideia de que nas tratativas os contratantes não ajam de modo a causar danos à contraparte. No que toca aos deveres de informação, estariam abarcados todos os esclarecimentos necessários e exatos para uma conclusão honesta do contrato; por exemplo, índices aplicáveis, variações e riscos. Por fim, aos deveres de lealdade, insere-se a adoção de comportamentos coerentes, não contraditórios (CORDEIRO, 2015, p. 583). 
Rogério Donnini (2011, p. 166), seguindo posição também encontrada em Menezes Cordeiro, entende que a boa-fé objetiva alcança a fase pós-contratual (culpa post pactum finitum):

\begin{abstract}
Embora o art. 422 do Código Civil tenha uma redação pouco precisa, indiscutivelmente em todas as fases (pré-contratual, contratual e pós-contratual) está ínsito o dever de boa-fé e probidade, mesmo porque se trata de cláusula geral, que impõe essa atitude de probidade e correção não somente nas relações contratuais, mas também em qualquer outra relação jurídica, comando esse de ordem pública, consoante estabelecido no parágrafo único do art. 2035 do Código Civil.
\end{abstract}

No que toca à especificidade da boa-fé objetiva nos contratos de previdência complementar privada, Judith Martins-Costa teve parecer colacionado nos autos do Recurso Especial n. 1.435.837/RS (BRASIL, 2019), pelo qual menciona o "feixe de direitos, obrigações, deveres secundários, deveres de proteção, deveres formativos, ônus e faculdades”, estando entre eles os deveres de garantir a segurança previdenciária e financeira dos participantes.

Assim, o parecer provoca o então relator, Paulo de Tarso Sanseverino, cujo voto resultou vencido, a concluir que, no contrato previdenciário (a hipótese se restringia ao regime fechado), a alteração de uma garantia prévia de definição de um benefício no curso do contrato violaria princípios de segurança jurídica e proteção da confiança, tão caros na hipótese dos contratos relacionais e consolidados no regime pátrio.

Aliás, mudanças que signifiquem alteração do benefício contratado, sem a prévia e adequada informação ao participante, implicam abuso de direito, ainda que haja uma flexibilidade contratual para tanto. Tudo isso decorre justamente da relação longa e duradoura estabelecida entre as partes e até mesmo dos direitos envolvidos, que extrapolam a autonomia contratual e afetam diretamente a humanidade do contratante, que espera contar com o benefício na velhice. Ao fim e ao cabo, tem-se que a tutela da confiança consiste em garantir aos contratantes que um certo estado de coisas, ao qual eles tenham sido levados a crer, seja mantido, quando justificável (CORDEIRO, 2016, p. 107).

Veja-se que a alteração de conduta que provoque a quebra da confiança, quando analisada individualmente, não necessariamente se mostra ilícita. A ideia consiste, em verdade, na percepção de que as condutas, quando analisadas sob o fundamento axiológico-normativo, mostram-se incoerentes (SCHREIBER, 2016, p. 75).

Merece atenção decisão do tribunal de Justiça de São Paulo no mês de maio de 2019, autos do recurso de Apelação Cível n. 1010936-24.2018.8.26.0071 (SÃO PAULO, 2019), sob a relatoria do desembargador Felipe Ferreira, justamente por invocar a tutela da confiança em contrato de previdência privada. Na hipótese, o participante aderiu a um plano de previdência privada no ano de 1971, tendo contribuído regularmente por longos 47 anos. 
Ocorre que no ano de 1991, sem a adequada transparência e informação, o contrato foi alterado para afastar o direito à aposentadoria complementar e manter apenas o direito à pensão aos beneficiários em caso de morte. O tribunal, com fundamento no Código de Defesa do Consumidor, decretou a nulidade da alteração contratual sob o argumento de quebra dos deveres anexos consistentes na confiança depositada após tantos anos de contratação e na ausência de informação adequada, considerando o aditamento do contrato evidente violação da boa-fé objetiva.

Não se olvide que a boa-fé objetiva ventilada nos contratos de previdência privada independe da incidência ou não do Código de Defesa do Consumidor, pois é ditame de direito contratual imposto, antes de mais nada, pelo Código Civil em seu artigo 422, cujo teor é cláusula geral e preceito de ordem pública, como já mencionado alhures.

Portanto é indiferente, neste particular, a posição adotada pelas cortes superiores, de que os contratos de previdência privada sob o regime fechado não são regidos pela legislação consumerista, dada a natureza de fundação e sociedade civil, entendimento esse pacificado pela Súmula n. 563 do Superior Tribunal de Justiça.

Por fim, convém salientar que a boa-fé objetiva consagra ao menos três funções na análise contratual, segundo lição de Judith Martins-Costa (2018, p. 485, 561, 625). A função interpretativa (art. 113 do Código Civil), a função integrativa (art. 422 do Código Civil) e a função de correção (art. 187 do Código Civil).

A função interpretativa desperta particular atenção, pois recai justamente sobre a análise dos contratos de adesão, formato pelo qual se constituem os contratos de previdência privada. Quando se trata de interpretar cláusulas pré-fixadas é imperioso que a dúvida beneficie aquele que não pôde redigir ou debater o conteúdo do negócio, como prevê o próprio Diploma Civil e o Código de Defesa do Consumidor.

É o caso, por exemplo, do supramencionado REsp n. 1201529 (BRASIL, 2015), pelo qual a recorrida, pessoa física, reivindicava em juízo a retomada de um contrato celebrado por seu falecido marido em 1950, porém novado, por orientação da instituição de previdência privada, no ano de 1983, regime adotado até a morte do contratante, cujos benefícios contemplariam sua viúva.

O Superior Tribunal de Justiça afastou os direitos da viúva sob o fundamento da decadência, com o qual não se discorda; contudo, não se pode deixar de apontar que, não houvesse prosperado a tese preliminar, o reconhecimento da classificação do contrato previdenciário como relacional admitiria uma discussão mais profunda quanto à alteração das condições do negócio, em 1983, para um regime jurídico mais gravoso ao beneficiário, sem a correta observância do dever anexo de informação. 
Verifica-se no caso concreto contrato cujos efeitos iniciaram-se em 1950, renovaram-se em 1983 e cujo debate encerrou-se no ano de 2015. São basicamente sessenta e cinco anos de relação jurídica entre as partes, estabelecendo liame de confiança que deveria atingir patamares diferenciados. Dito isso, é mister reconhecer que, ao analisar negócios da mesma natureza, o Poder Judiciário não pode desprezar a aliança criada entre os sujeitos e, principalmente, os efeitos que aquela contratação propaga na vida do segurado e seus beneficiários.

Nesse ponto, fundado na boa-fé objetiva e no dever anexo de informação, as alterações contratuais que se estabelecem em contratos de previdência privada, por exemplo, merecem interpretação rígida em favor do aderente, tanto para contemplar aquele que se coloca em posição vulnerável, quanto para advertir as instituições privadas. Tais medidas poderiam ser representadas, por exemplo, por projeções claras e transparentes para o futuro, encerrando margem para anulações ou revisões contratuais desnecessárias.

Referida concepção decorre do dever lateral de informação, ou de transparência, concretizador da boa-fé objetiva e utilizado, por exemplo, na jurisprudência colacionada.

A função integrativa, de outra volta, foi mencionada alhures, quando da referência à incidência das regras de probidade e boa-fé em todas as fases do contrato, desde as tratativas e até no momento posterior a ele. Concentra-se na ideia de que a eticidade deve integrar a relação negocial por todo o seu percurso, isto é, momento pré-contratual, momento contratual e momento póscontratual. A tese foi consolidada na I Jornada de Direito Civil do Conselho de Justiça Federal, conforme Enunciado n. 25, que dispõe: “O art. 422 do Código Civil não inviabiliza a aplicação pelo julgador do princípio da boa-fé nas fases pré-contratual e pós-contratual.”

Nesse particular, é interessante ponderar que as seguradoras, antes da contratação, analisam uma série de características do pretenso segurado, bem como dos beneficiários, nem sempre informando de forma clara e precisa quais dados são fundamentais para a elaboração da proposta de previdência que será apresentada ao interessado, que se submete ao regime jurídico apontado com baixíssima margem para discussão.

A tendência de proteção já na fase de tratativas e que se estenderá ao regime de previdência privada é confirmada, por exemplo, com a recente aprovação da Lei Geral de Proteção de Dados (Lei $n^{0}$ 13.709/2018), pela qual a informação quanto aos critérios para a celebração do contrato e a revisão da proposta apresentada serão direitos expressos, cuja observância deve ser tida como norte antes mesmo da contratação (boa-fé objetiva na fase pré-contratual). Destarte, ao elaborar o plano de previdência, a entidade que construir o perfil do pretenso contratante por meio do tratamento de dados 
está obrigada a manter transparência quanto aos critérios utilizados com o fito de justificar as decisões que disso decorrem.

A função de controle, por fim, revelará a responsabilização do contratante que no curso do negócio provoque traços de abusividade ou desequilíbrio, seja a negociação por adesão ou não; na hipótese, um exemplo clássico de situação que merece particular atenção é a resilição unilateral por parte da instituição financeira após longos períodos de contratação, para forçar a adesão a planos mais onerosos; ou ainda, inserção de tarifas não contratadas previamente, com descontos por meio de débito automático, dificultando a percepção do segurado quanto a eventuais excessos que não reverterão em seu favor e que tampouco encontram-se contemplados pelos custos contratuais já assumidos.

As regras atinentes à boa-fé objetiva tomaram tamanha proporção que sua violação é conhecida por violação positiva do contrato, permitindo eventualmente que, muito embora os deveres nucleares venham sendo cumpridos, a quebra de um dever anexo provoque a resolução do negócio.

É curioso como o filtro da boa-fé objetiva ainda é incipiente na análise da jurisprudência que cerca os contratos de previdência privada, ao contrário, por exemplo, do que se verifica em seguros saúde ou em discussões de empréstimos bancários. Todavia, parece indispensável a abertura do debate quanto aos deveres anexos presentes na contratação da previdência privada, dada a perspectiva de futuro que carrega e o longuíssimo prazo pelo qual se desenvolve.

\section{A FUNÇÃO SOCIAL NOS CONTRATOS DE PREVIDÊNCIA PRIVADA}

No início deste trabalho foi mencionada a perspectiva constitucional da previdência privada, como um braço da seguridade social e um complemento ao regime geral. Nesse sentido, sendo a seguridade social um conjunto de medidas que visam outorgar a dignidade em plenitude à população por meio do emprego, da saúde e do combate à pobreza, impõe compreender em quais proporções o contrato de previdência complementar contribui.

Em verdade, ante o absoluto declínio do regime previdenciário estabelecido e a crise da perspectiva de welfare state, as entidades de previdência privada passaram a exercer papel de destaque como um ponto de equilíbrio na tentativa de viabilizar conforto àqueles que contribuem para o regime geral e não encontram no momento da aposentaria um rendimento compatível com o custo de vida praticado.

O regime obrigatório hoje contém uma categoria mais ampla de beneficiários, notadamente após a Constituição da República de 1988, justamente pelos valores solidaristas que contempla. A 
forma constitucional atual possibilita a aplicação de regramento mais flexível para favorecer a inclusão de categorias como donas de casa, trabalhadores rurais, profissionais liberais e, portanto, não é centrada exclusivamente nos trabalhadores registrados (ANSILIERO; PAIVA, 2008, p. 3).

Diante de realidade tal, é imperioso identificar como o contrato de previdência privada se enquadra nesse contexto de Estado social. Isso porque contrato não pode ser compreendido exclusivamente como conceito jurídico, mas como um reflexo da realidade econômico-social que lhe subjaz, ou seja, uma expressão dos reais interesses que estão em jogo (ROPPO, 2009, p. 7-8).

Ronaldo Porto Macedo Junior (1998, p. 318-319) traduz a ideia para a perspectiva da previdência:

o sistema privado de pensão não pode ser pensado fora do contexto da intervenção estatal que o forjou e definiu seu papel institucional. Essa natureza social do sistema previdenciário privado decorre, não apenas em termos das ações do Estado, quando ele gasta e como ele legisla, mas também de como ele se relaciona com os mercados privados, definindo o arranjo institucional do mercado de previdência privada.

É certo que a previsão da previdência privada na norma constitucional traduz com bastante clareza o fenômeno da constitucionalização do direito privado e do próprio direito civil constitucional, expressão adotada pelo italiano Pietro Perlingieri (2007). A previdência complementar, braço do regime geral obrigatório, concretiza-se por meio de um instituto eminentemente civil, que é o contrato.

Por essa razão, é a sombra soberana da Constituição da República que se deita sobre a legislação ordinária aplicável à espécie. Com isso, entrega-se ao civilista a oportunidade de “individuar um sistema [...] mais harmonioso aos princípios fundamentais e, em especial, às necessidades existenciais da pessoa” (PERLINGIERI, 2007, p. 12).

É preciso não perder de vista que a previdência social, como um todo, implica a distribuição de renda de modo a garantir à sociedade a redução das desigualdades e acesso às necessidades correlatas à manutenção de sua dignidade. Contudo, a previdência social, sob o regime geral, tem como meta o atendimento das necessidades essenciais, outorgando ao regime privado tudo aquilo que exceda de algum modo tal limite (NOGUEIRA, 1985, p. 23) e que pela via contratual contribua para a solidariedade constitucional, a igualdade em sentido amplo e uma ordem econômica e social equilibrada, assegurando os ditames da justiça e a função social da propriedade (TARTUCE, 2007, p. 74).

Por essa mesma razão, Rio Nogueira (1985) insistia na compreensão de que ao Estado caberia apenas e tão somente a gestão da previdência pública obrigatória, outorgando à previdência privada a responsabilidade pela administração da seguridade supletiva. 
Não há como afastar, portanto, a ideia de que na previdência privada a relação jurídica estabelecida implicará uma análise concomitante da autonomia privada, do pacta sunt servanda e dos interesses sociais atribuíveis à relação.

Nesse contexto, mostra-se particularmente relevante o teor do artigo 421 do Código Civil, que contempla a cláusula geral da função social dos contratos. O referido dispositivo mitiga a liberdade contratual, como exercício da autonomia privada, em razão e nos limites da função social.

É possível dizer, assim, que ao funcionalizar os negócios jurídicos bilaterais, o legislador impôs filtro, que em sentido amplo significa dizer: não basta que o contrato seja bom para os contratantes, ele deve ser bom para a sociedade como um todo.

Pela mesma razão, é oportuna a colocação de Paulo Nalin (2005, p. 255), que conceitua contrato como sendo "Relação jurídica subjetiva, nucleada na solidariedade constitucional, destinada à produção de efeitos jurídicos existenciais e patrimoniais, não só entre os titulares subjetivos da relação, como também perante terceiros”. Verifica-se no conceito a proteção da pessoa humana e a perspectiva externa dos contratos, isto é, contratos produzem efeitos para a coletividade e, portanto, devem considerar os valores constitucionais, não apenas para garantir o equilíbrio interno da relação, mas também para promover os valores da República.

Diversa não é a conclusão de Wagner Balera (2014, p. 128), ao aduzir que ao intérprete cabe encontrar o sentido mais abrangente das cláusulas contratuais a fim de encampar a função social que lhes é exigível: “A costura inicial, ideal para determinada modalidade de proteção previdenciária, tem como pressuposto a função social, diríamos melhor, de proteção social, do contrato que as partes pretendem celebrar”.

É necessário concluir, portanto, que o contrato de previdência privada garante, por via paralela à estatal, o direito social à aposentadoria, previsto no artigo $7^{\circ}$, inciso XXIV, da Constituição Federal, deferida àqueles que já não se encontram em fase ativa da vida, ou por terem completado o ciclo de contribuições ou por moléstias incapacitantes. Veja-se que sob qualquer perspectiva, a previdência, seja pública, seja complementar, alcança um grupo de vulneráveis pela idade ou pela condição de saúde.

Inseridas nesse papel, as contratações de previdência privada visam suplantar riscos sociais decorrentes da invalidez, da doença, da idade avançada e até mesmo da morte, razão pela qual não poderiam ser tomadas por uma ótica exclusivamente patrimonial, típica de uma análise fria e clássica dos contratos. Representam serviços privados de indiscutível interesse público.

Justamente por envolver uma possibilidade de exploração privada de atividade desempenhada na essência pelo Estado, contratações como as ora debatidas merecem um dirigismo 
estatal mais acentuado, por não se tratar de mera atividade econômica, mas de um serviço de relevância pública (PULINO, 2011, p. 52-54). Não se trata de transpor aos entes privados a obrigação estatal, mas, uma vez respeitada a livre iniciativa, elevar determinadas relações privadas a um patamar de maior importância.

Conceber a Constituição da República como carta política dotada de normatividade é fundamental para enrijecer a interpretação dos negócios jurídicos. Se o Código Civil brasileiro hoje consagra a função social dos contratos, o faz em tom indicativo despatrimonializador e publicizador do direito privado.

Assim, quando se coloca que a liberdade contratual é o sustentáculo dos contratos, também há que se concluir que só se sagrará plena quando contida nos ideais constitucionais, sob pena de, em vez, de libertar, oprimir. Nesse ponto, inserir a previdência privada na Carta Magna também significa romper com a percepção abstrata e atomizada dos direitos e garantias, bem como com princípios da República, mormente por indicar ao mercado diretrizes básicas para o desenvolvimento de suas atividades.

Essa conclusão faz parte da própria compreensão de sistema, superando a fragmentação entre o público e o privado, não para igualá-los, mas para identificar que existe uma unidade da qual será extraído o espírito legislativo. Nesse sentido, é oportuna a colocação de Eduardo García de Enterría (1985, p. 19), de que “No es posible en plano técnico, simplemente, manejar el ordenamiento, aun para resolver un problema menor, sin considerar a dicho ordenamiento como una unidad y, por tanto, sin la referencia constante a la Constitución [...]”, mormente quando se trata de negócio privado expressamente abraçado pela norma fundamental, como é o caso da previdência privada.

A função social dos contratos, é, pois, um dos filtros de intervenção estatal nos contratos de previdência privada. Primeiro, sob o ponto de vista da sua eficácia interna, a função social tem como fundamento a garantia de que os contratantes se encontrem em posição de equilíbrio, evitando, por sua vez, que o negócio jurídico funcione como instrumento de opressão de uma parte sobre a outra. Essa eficácia interna da função social do contrato garante, por exemplo, que o negócio tenha sua finalidade preservada e que as partes se posicionem em substancial igualdade à luz das escolhas valorativas do sistema (GODOY, 2004, p. 129).

Há também parte da doutrina que outorga à função social uma eficácia externa, notadamente para disciplinar os efeitos da relação contratual perante terceiros ou, ainda, efeitos que terceiros estranhos ao negócio possam implicar a uma relação equilibrada. A eficácia externa atende em boa parte a ideia de repersonalização das relações privadas defendida como modelo de aplicação para os contratos relacionais de previdência, já que reconhece o movimento e o desenvolvimento do mercado 
desde que os seus fomentadores vislumbrem a consagração de seus direitos fundamentais para além da noção de empresa e propriedade.

Seria raso compreender que a previdência privada atende apenas aos objetivos da livre iniciativa, visando ao lucro, quando dali decorrem valores concretizadores da dignidade da pessoa humana, na medida em que potencializa uma velhice com maior conforto, por meio da viabilização de recursos que irradiam para a saúde, moradia, segurança e diversos direitos fundamentais do segurado.

A bem da verdade, é possível identificar que o princípio da função social dos contratos implica a celebração de três vetores básicos: ordem econômico-social para geração e circulação de riquezas, o bem comum e o equilíbrio entre os sujeitos contratantes (REBOUÇAS, 2017, p. 91).

Não há dúvidas de que a função social dos contratos é cláusula geral a ser observada pelo magistrado na análise de planos de previdência privada, até mesmo pelo seu caráter de ordem pública estabelecido pelo artigo 2.035, parágrafo único, do Código Civil. De outra parte, cabe ao julgador se afastar de convicções subjetivistas, políticas ou pessoais para eventualmente interferir na relação negocial, isso porque decisões pontuais que alterem um ou outro contrato acabam por enfraquecer o sistema como um todo. O fundamento para tanto é que, embora o conteúdo dos contratos de previdência privada seja a consagração da seguridade social, é mediante atividade privada que se desenvolve.

Decisões que enfraqueçam a autonomia privada sem justificativas técnicas aptas a apontar a ofensa ao equilíbrio e à justiça contratual acabam por culminar em insegurança jurídica e insegurança “quanto ao aspecto econômico do contrato” (REBOUÇAS, p. 99), elevando custos de operações e reduzindo investimentos justamente das entidades motoras da promoção de um serviço privado de relevância social.

O desafio é gritante. De um lado, há a perspectiva privada das contratações, e de outro, direitos sociais a serem concretizados na interpretação dos negócios jurídicos de previdência privada pelo magistrado, cuja tarefa não se restringe mais ao simples sentido de julgar certo e errado com base na lei, "mas também e sobretudo examinar se o exercício do poder de legislar conduz à concretização dos resultados objetivados” (FERRAZ JUNIOR, 2014, p. 124).

Nesse particular, seria possível apontar que, entre as possíveis justificativas técnicas, ao juiz somente seria possível revisar contratos de previdência privada pela quebra da função social, quando identificado que as condições do negócio colocam o aderente em excessiva desvantagem, seja em razão de cálculos atuariais e atualizações questionáveis ou contrárias ao estabelecido pelas entidades regulamentadora competentes, seja por embaraços no acesso às prestações, permitindo que o 
segurado ou o beneficiário caiam em estado de extrema dificuldade para acessar prestações a que teriam direito, colocando em risco inclusive sua saúde e sobrevivência, em afronta direta ao fundamento da dignidade humana.

\section{CONSIDERAÇÕES FINAIS}

Ao longo do trabalho foi possível identificar que o momento econômico e político brasileiro afeta a compreensão dos contratos de previdência privada, dadas a insegurança quanto às reformas anunciadas pelo governo e as incertezas quanto ao seu conteúdo.

Trata-se de reconhecer que referidos contratos, regulamentados num passado recente, oferecem um serviço de relevância pública, na medida em que ajudam a concretizar valores constitucionalmente protegidos, outorgando aos participantes a expectativa de uma velhice confortável; todavia, os questionamentos com base em seu teor constitucional e na função social que representam são pouco observados na jurisprudência pátria, com decisões incipientes e que pouco vinculam a interpretação do negócio à sua natureza de contrato relacional.

Naturalmente, não se pode perder de vista que os contratos de previdência complementar são fruto do exercício da autonomia privada, dada sua natureza facultativa. Por essa razão, é fundamental que os participantes e as entidades envolvidas possam contar com o pacta sunt servanda como elemento inafastável.

De outro lado, há um desafio axiológico inserido no objeto da contratação, que extrapola a perspectiva patrimonial, atingindo questões humanas existenciais, algo que se torna especialmente importante ante a tendência de se prolongar indefinidamente no tempo, de forma excepcionalmente duradoura. Daí por que as expectativas fomentadas no participante devem ser consideradas em maior grau e, por sua vez, provocar uma análise sob a ótica da boa-fé objetiva e da função social dos contratos, consagradas pelo Código Civil brasileiro.

Esse prolongamento no tempo, como dito, enquadra os contratos de previdência privada na categoria de contratos cativos de longa duração - expressão bem contemplada no Brasil por Cláudia Lima Marques -, também chamados contratos relacionais. Isso porque, em algumas relações negociais, o grau de tutela de confiança precisa elevar-se considerando a dinâmica da relação desenvolvida.

Por estarem classificados como contratos relacionais e por tratarem de questões existenciais, os contratos de previdência complementar demandam uma incidência em maior proporção das cláusulas gerais de boa-fé objetiva e de função social dos contratos. 
Não se trata aqui de dizer que a autonomia privada restou enfraquecida, mas de compreender que a relação contratual hoje não reflete apenas uma demanda de ordem econômica, mas também social, em busca do bem comum e do equilíbrio. No caso dos contratos de previdência privada, temse um claro braço auxiliar da seguridade social, que em poucas palavras visa adequar a distribuição de renda e reduzir a pobreza, não como um substituto dos deveres estatais, mas como uma negociação privada que, a despeito das múltiplas formas contratuais possíveis, foi elegida pelo constituinte para receber especial atenção, dados os valores que ajuda a promover. Seria leviano ignorar que os contratos de previdência privada possuem particularidade que extrapola a grande maioria das negociações entabuladas pela livre-iniciativa. Tampouco pode-se minimizar que seus efeitos mediatos irradiam na qualidade de vida dos segurados, promovendo sua saúde, segurança, moradia e diversos outros primados da pessoa humana.

São relações que se estabelecem pela via da adesão e que podem ou não, a depender da natureza aberta ou fechada, receber as normas do Código de Defesa do Consumidor. Insta destacar que, em qualquer hipótese, o contrato de previdência privada submete-se ao crivo da boa-fé objetiva e da função social dos contratos.

No primeiro caso, sendo tratativa de adesão, deve prestigiar os deveres anexos de confiança, colaboração, transparência e informação, de modo que o participante obtenha ao final o resultado pretendido dentro das expectativas apresentadas no ato da contratação. Por essa mesma razão, os tribunais têm limitado, e até mesmo anulado, alterações contratuais que não sejam claras, assim como impedido a resilição unilateral imotivada após muitos anos de contratação.

No que toca à função social, fica evidente que o contrato de previdência privada garante aos contratantes uma série de prestações afetas à dignidade humana, pois utilizadas na velhice como fonte de renda. Daí por que não basta a esse contrato ser bom para os sujeitos, é preciso que ele reproduza os valores do solidarismo constitucional e da justiça social como reflexo de uma sociedade equilibrada. Posto isso, a liberdade contratual será ampla enquanto não atingir os valores supramencionados.

Não se trata de concluir que as entidades de previdência privada passam a ser reféns de um dirigismo estatal, porém de incentivá-las à produção de contratações equilibradas, sempre dentro de uma conduta ética, leal e proba. Evita-se, assim, que o contrato se transforme em instrumento de opressão ou de exploração de vulnerabilidades, notadamente quando o conteúdo da negociação é de relevância pública, funcionando como um complemento ao ideal de seguridade social pregado pela Carta Magna de 1988. Somente nessas hipóteses de ofensa o Poder Judiciário poderá agir para retomada do equilíbrio das prestações, inclusive revisando o negócio. 
É imperioso concluir que o equilíbrio das prestações também envolve uma economia pungente, que depende da segurança jurídica dos contratos, razão pela qual a intervenção com bases nos filtros propostos deve considerar aspectos técnicos e objetivos, sob pena de macular os investimentos das entidades que promovem esse setor privado, cuja relevância social é tamanha.

Obtempera-se no sentido de que os referidos aspectos técnicos são aqueles que levam em conta a natureza cativa e de adesão do contrato, os riscos assumidos e a posição dos sujeitos, de modo a atender interesses coletivos, mais do que individuais. Sendo assim, sob o fundamento da função social, os contratantes estariam aptos a questionar o desequilíbrio das prestações desencadeado por cálculos atuariais ou atualizações que fogem aos padrões estabelecidos pelas entidades competentes, assim como pleitear a derrubada de entraves administrativos que, injustificadamente, atrasem ou condicionem o acesso às prestações, causando prejuízos graves ao segurado ou a beneficiários na obtenção do bem da vida, representado mediatamente, como já dito, por direitos e garantias fundamentais na busca por uma existência digna.

Finalmente, é em tom de crítica que se constata, nas decisões judiciais e em trabalhos acadêmicos, a diminuta vinculação da natureza cativa aos contratos de previdência, apta a justificar fundamentos calcados na boa-fé objetiva e na função social dos contratos (princípios basilares da codificação civil pátria) como consagradores do vetor estabelecido à Constituição Federal de 1988, assim resultando em teses que ainda parecem reproduzir, nesse ponto peculiar, uma visão fragmentada entre a norma constitucional e o direito contratual.

\section{REFERÊNCIAS}

AGUIAR JÚNIOR. Ruy Rosado de. Contratos relacionais, existenciais e de lucro. Revista Trimestral de Direito Civil, Rio de Janeiro, ano 12, v. 45, p. 91-110, jan.-mar. 2011.

ANSILIERO, Graziela; PAIVA, Luís Henrique. La reciente evolución de la cobertura de la seguridad social en el Brasil. Revista Internacional de Seguridad Social, [s. l.], v. 61, n. 3, p. 130, mar. 2008.

BALERA, Wagner. Da proteção social à família. In: CAHALI, Francisco José; CAHALI, Yussef Said (org.) Doutrinas Essenciais. Famílias e Sucessões. V. 1. São Paulo: Revista dos Tribunais, 2011. p. 361-396.

BALERA, Wagner. Sistema de seguridade social. 7. ed. São Paulo: LTr, 2014.

BALERA, Wagner; MUSSI, Cristiane Miziara. Direito Previdenciário. 7. ed. São Paulo: Método, 2010. 
BONAVIDES Paulo. Curso de Direito Constitucional. 15. ed. São Paulo: Malheiros, 2004.

BRASIL. Constituição da República Federativa do Brasil de 1988. Diário Oficial da União, Brasília, DF, 5 out. 1988. Disponível em: https://bit.ly/34DqD4X. Acesso em: 29 jun. 2019.

BRASIL. Lei Complementar $n^{\circ}$ 108, de 29 de maio de 2001. Dispõe sobre a relação entre a União, os Estados, o Distrito Federal e os Municípios, suas autarquias, fundações, sociedades de economia mista e outras entidades públicas e suas respectivas entidades fechadas de previdência complementar, e dá outras providências. Diário Oficial da União, Brasília, DF, 30 maio 2001a. Disponível em: https://bit.ly/2K86OJk. Acesso em: 29 jun. 2019.

BRASIL. Lei Complementar $n^{\circ}$ 109, de 29 de maio de 2001. Dispõe sobre o Regime de Previdência Complementar e dá outras providências. Diário Oficial da União, Brasília, DF, 30 maio 2001b. Disponível em: https://bit.ly/2XNiM3p. Acesso em: 29 jun. 2019.

BRASIL. Lei ${ }^{0}$ 10.406, de 10 de janeiro de 2002. Institui o Código Civil. Diário Oficial da União, Brasília, DF, 11 jan. 2002. Disponível em: https://bit.ly/2V6Jv94. Acesso em: 29 jun. 2019.

BRASIL. Lei ${ }^{\circ}$ 8.078, de 11 de setembro de 1990. Dispõe sobre a proteção do consumidor e dá outras providências. Diário Oficial da União, Brasília, DF, 12 set. 1990 - Edição extra e retificado em 10 jan. 2007. Disponível em: https://bit.ly/3b9YftF. Acesso em: 29 jun. 2019.

BRASIL. Superintendência Nacional de Previdência Complementar (Previc). Sobre o setor. Previc, Brasília, 20 nov. 2014a. Disponível em: https://bit.ly/3ckmSUE. Acesso em: 26 jun. 2019.

BRASIL. Superior Tribunal de Justiça (2 ${ }^{a}$ sessão). Recurso Especial ${ }^{\circ} 1201529 / R S . ~ R E C U R S O$ ESPECIAL. PREVIDÊNCIA PRIVADA. REVISÃO DE PENSÃO. ÍNDICE DE CONTRIBUIÇÃO. FAIXA ETÁRIA. RENDA MENSAL INICIAL. REVISÃO DO CÁLCULO. NEGÓCIO JURÍDICO. VÍCIO DE CONSENTIMENTO. ANULAÇÃO. DECADÊNCIA [...]. Recorrente: MBM Previdência Complementar. Recorrido: Alice Machado Sofia. Relatora para acórdão: Min. Maria Isabel Gallotti. DJe, Brasília, DF, 1 jun. 2015.

BRASIL. Superior Tribunal de Justiça (2a sessão). Recurso Especial no 1435837/RS. RECURSO ESPECIAL REPETITIVO. DIREITO CIVIL. PREVIDÊNCIA PRIVADA. APOSENTADORIA COMPLEMENTAR. CONCESSÃO. CÁLCULO DA RENDA MENSAL INICIAL.

REGULAMENTO DA ÉPOCA DO PREENCHIMENTO DOS REQUISITOS DO BENEFÍCIO. INCIDÊNCIA. NORMAS REGULAMENTARES VIGENTES NA DATA DA ADESÃO. AFASTAMENTO. DIREITO ADQUIRIDO. INEXISTÊNCIA. DIREITO ACUMULADO. OBSERVÂNCIA. REGIME DE CAPITALIZAÇÃO. FUNDO MÚTUO. PRÉVIO CUSTEIO. EQUILÍBRIO ECONÔMICO-ATUARIAL. PRESERVAÇÃO [...]. Recorrente: Fundação Banrisul de seguridade social. Recorrido: Ronaldo Ximenes Carneiro. Relator para voto: Min. Ricardo Villas Boas Cueva. DJe, Brasília, DF, 1 out. 2019.

BRASIL. Superior Tribunal de Justiça (3 $3^{a}$ Turma). Recurso Especial n ${ }^{0}$ 1294093/RJ. CIVIL E CONSUMIDOR. RECURSO ESPECIAL. SEGURO DE VIDA EM GRUPO. RENOVAÇÃO AUTOMÁTICA POR 5 (CINCO) ANOS. DENÚNCIA UNILATERAL DA SEGURADORA MEDIANTE PRÉVIA COMUNICAÇÃO. POSSIBILIDADE. ARTIGOS ANALISADOS: ARTS. 187; 421 E 422 DO CÓDIGO CIVIL [...]. Recorrente: Patrícia Haley Cortes e outro. Recorrido: Allianz Seguros S.A. Relatora: Min. Nancy Andrighi. DJe, Brasília, DF, 24 abr. 2014b. 
BUCCI, Maria Paula Dallari. O conceito de política pública em direito. In: BUCCI, Maria Paula Dallari (org.) Políticas Públicas: reflexões sobre o conceito jurídico. São Paulo: Saraiva, 2006.

CORDEIRO, António Manuel da Rocha e Menezes. Da boa-fé no direito civil. 6. reimpr. Coimbra: Almedina, 2015.

CORDEIRO, António Manuel da Rocha e Menezes. Litigância de má-fé, Abuso do Direito de Ação e Culpa “in agendo”. 3. ed. Coimbra: Almedina, 2016.

DONNINI, Rogério Ferraz. Responsabilidade civil pós-contratual: no Direito Civil, no Direito do Consumidor, no Direito do Trabalho, no Direito Ambiental e no Direito Administrativo. 3. ed. São Paulo: Saraiva, 2011.

ENTERRÍA, Eduardo García de. La Constitución como Norma y el Tribunal Constitucional. 3. ed. Madrid: Civitas, 1985.

FEDERAÇÃO NACIONAL DE PREVIDÊNCIA PRIVADA E VIDA (FenaPrevi). Previdência complementar aberta fecha semestre com R\$ 55,7 bilhões em contribuições, registrando expansão de 8,3\% frente ao primeiro semestre de 2018. FenaPrevi, Rio de Janeiro, 30 ago. 2019. Disponível em: https://bit.ly/3elBt3V. Acesso em: 14 nov. 2019.

FERES, Marcos Vinícius Chein; DIAS, João Paulo Torres. Teoria geral dos contratos relacionais. In: FACHIN, Luiz Edson; TEPEDINO, Gustavo (org.). Doutrinas Essenciais. Obrigações e Contratos. V. 3. São Paulo: Revista dos Tribunais, 2011. p. 329-342.

FERRAZ JUNIOR, Tércio Sampaio. O direito entre o futuro e o passado. São Paulo: Noeses, 2014.

GODOY, Cláudio Luiz Bueno de. Função Social do Contrato: os novos princípios contratuais. São Paulo: Saraiva, 2004.

MACEDO JUNIOR, Ronaldo Porto. Contrato previdenciário como contrato relacional. In: MARQUES, Claudia Lima; MIRAGEM, Bruno (org.) Doutrinas Essenciais. Direito do Consumidor. V. 4. São Paulo: Revista dos Tribunais, 2011a. p. 1.071-1.086.

MACEDO JUNIOR, Ronaldo Porto. Contratos relacionais e defesa do consumidor. São Paulo: Max Limonad, 1998.

MACEDO JUNIOR, Ronaldo Porto. Direito à informação nos contratos relacionais de consumo. In: MARQUES, Claudia Lima; MIRAGEM, Bruno (org.) Doutrinas Essenciais. Direito do Consumidor. V. 3. São Paulo: Revista dos Tribunais, 2011b. p. 663-673.

MACEDO JUNIOR, Ronaldo Porto. Ensaios de teoria do Direito. São Paulo: Saraiva, 2013.

MACNEIL, Ian R. Reflections on relational contract theory after a neo-classical seminar. In: CAMPBELL, David; COLLINS, Hugh; WIGHTMAN, John (org.) Discrete, Relational and Network Contracts. Oxford: Hart Publishing, 2003. 
MARQUES, Cláudia Lima. Contratos no Código de Defesa do Consumidor: o novo regime das relações contratuais. 2. ed. rev. ampl. São Paulo: Revista dos Tribunais, 1995.

MARQUES, Cláudia Lima. Contratos no Código de Defesa do Consumidor. 3. ed. rev., atual., e ampl. São Paulo: Revista dos Tribunais, 1998.

MARTINS-COSTA, Judith. A boa-fé no direito privado: critérios para a sua aplicação. 2. ed. São Paulo: Saraiva, 2018.

MUSSI, Cristiane Miziara. A Previdência Social como política pública de distribuição de rendas e de inclusão social. In. ATIQUE, Henry; SIQUEIRA, Dyrceu Pereira (org.) Ensaios sobre os Direitos Fundamentais e Inclusão Social. Birigui: Boreal, 2010.

NALIN, Paulo. Do contrato: conceito pós-moderno. Curitiba: Juruá, 2005.

NOGUEIRA, Rio. A crise moral e financeira da previdência social. São Paulo: Diefel, 1985.

PERLINGIERI, Pietro. Perfis do Direito Civil: introdução ao direito civil constitucional. Rio de Janeiro: Renovar, 2007.

PERSIANI, Mattia. Lezioni di diritto della previdenza sociale. Padova: Cedam, 2014.

PULINO, Daniel. Previdência Complementar: natureza jurídico-constitucional e seu desenvolvimento pelas entidades fechadas. São Paulo: Conceito Editorial, 2011.

REBOUÇAS, Rodrigo Fernandes. Autonomia privada e análise econômica do contrato. São Paulo: Almedina, 2017.

ROPPO, Enzo. O contrato. Coimbra: Almedina, 2009.

SÃO PAULO. Tribunal de Justiça do Estado de São Paulo. 26a Câmara de Direito Privado. Apelação Cível n. 1010936-24.2018.8.26.0071. PREVIDÊNCIA PRIVADA. AÇÃO DE RESCISÃO CONTRATUAL C/C RESTITUIÇÃO DE VALORES. 1. O prazo prescricional só se inicia com a ciência do autor da negativa da ré em pagar a aposentadoria requerida. 2. Migração de plano realizada sem que fosse o autor informado sobre os diferentes tipos de planos. Novo plano que suprimia o direito a aposentadoria, apesar de os descontos em folha de pagamento indicarem que permaneceria vigente o plano de previdência privada. Ofensa à boa-fé objetiva e à função social do contrato, com vício do consentimento na adesão ao novo plano. 3. Rescisão dos contratos com restituições das contribuições vertidas - cabimento. Sentença reformada. Recurso provido para julgar a ação procedente. Recorrente: André Conca. Recorrido: CAPEMISA Seguradora de Vida e Previdência S.A. Relator: Des. Felipe Ferreira. Tribunal de Justiça de São Paulo, São Paulo, 24 maio 2019. Disponível em: https://bit.ly/34CgW6v. Acesso em: 29 jun. 2019.

SCHREIBER, Anderson. A proibição de comportamento contraditório: tutela de confiança e venire contra factum proprium. 4. ed. São Paulo: Atlas, 2016.

SILVA, Clóvis V. do Couto e. A obrigação como processo. Rio de Janeiro: Editora FGV, 2006. 
TAFNER, Paulo. Simulando o desempenho do sistema previdenciário e seus efeitos sobre pobreza sob mudanças nas regras de pensão e aposentadoria. Texto para Discussão [ $\mathrm{N}^{\circ}$ 1264, Instituto de Pesquisa Econômica Aplicada - Ipea], Rio de Janeiro, p. 1-39, mar. 2007.

TARTUCE, Flávio. Função social dos contratos: do Código de Defesa do Consumidor ao Código Civil de 2002. 2. ed. São Paulo: Método, 2007.

Francisco José Cahali

Mestre e Doutor em Direito Civil pela Pontifícia Universidade Católica de São Paulo. Coordenador do Núcleo de Direito Civil, professor na graduação em Direito e no PPGD da mesma instituição, nas disciplinas de Arbitragem, Direito Civil, Direito de Família e Sucessões e Princípios Gerais do Direito Civil.E-mail: francisco@cahali.adv.br

Danielle Portugal de Biazi Mestra em Direito Civil Comparado e doutoranda em Direito Civil pela Pontifícia Universidade Católica de São Paulo.E-mail: danielle@biaziadvogados.com.br 